\title{
High concentration of calcium ions in Golgi apparatus
}

\author{
XUE Shaobai ${ }^{1}$, M. Robert NICOUD, Jie CUI, D.J. \\ AR N D t JOVIN \\ Department of Biology, Beijing Normal University, Bei- \\ jing 100875, China \\ Max-Planck-Institute fSr Biophysikalische Chemie, \\ GSttingen, Germany
}

\section{ABSTRACT}

The interphase NIH3T3 cells were vitally fluorescentstained with calcium indicator fluo-3 and Glogi probe $\mathrm{C}_{6^{-}}$ NBD-ceramide, and then the single cells were examined by laser scanning confocal microscopy (LSCFM) for subcellular distributions of $\mathrm{Ca}^{2+}$ and the location of Golgi apparatus. In these cells, the intracellular $\mathrm{Ca}^{2+}$ were found to be highly concentrated in the Golgi apparatus. The changes of distribution of cytosolic high $\mathrm{Ca}^{2+}$ region and the Golgi apparatus coincided with the cell cycle phase. In calcium free medium, when the plasma membrane of the cells which had been loaded with fluo-3/AM were permeated by digitonin, the fluorescence of the Golgi region decreased far less than that of the cytosol. Our results indicated that the Glogi lumen retained significantly high concentration of free calcium.

Key words: intracellular free calcium, fluo-3/AM, Golgi apparatus, $C_{6}$-NBD-ceramide, laser scanning confocal microscopy, intracellular calcium store.

\section{INTRODUCTION}

A lot of studies demonstrated that many aspects of cell functions are regulated by the concentration of cytosolic free calcium[1]. Most cells produce changes in intracel-

1. Corresponding author 
Golgi apparatus concentrates high $\left[\mathrm{Ca}^{2+}\right] \mathrm{i}$

lular free calcium for signaling via $\mathrm{Ca}^{2+}$ channels in the surface membrane, and/or discharge calcium from intracellular stores[2,3]. But high $\left[\mathrm{Ca}^{2+}\right]$ i may do harm to the cell if it maintains a long time. Cells return $\left[\mathrm{Ca}^{2+}\right] \mathrm{i}$ toward its low physiological level through its $\mathrm{Ca}^{2+}$-ATPase on the plasma membrane or membrane of internal calcium pools. Thus, special structure for storing intracellular $\mathrm{Ca}^{2+}$ plays an essential role in calcium homeostasis. Although there is no question that sarcoplasmic reticulum (SR) is the intracellular calcium pools for muscle cells[4], the localization of non-mitochondrial calcium pool is much less clear in non-muscle system. Some authors considered that endoplasmic reticulum(ER) served as pools[5], while others though of a separate organelle termed as calciosome, playing the role[6,7]. For technical reason, it is impossible to measure the $\left[\mathrm{Ca}^{2+}\right] \mathrm{i}$ precisely in $\mathrm{ER}$ or calciosomes. That is to say the anatomical localization of the $\left[\mathrm{Ca}^{2+}\right]$ i store in non-muscle system remains unclear. Although Chandra et al observed a prominent perinuclear regional concentration of total calcium (both free and binding calcium) associated with the Golgi apparatus by laser scanning confocal microscopy(LSCFM) and ion microscopy[8], the storage of cytosolic free calcium has not been clearly defined yet. In the present study, calcium indicator fluo-3 /AM and Golgi probe $\mathrm{C}_{6}$-NBDceramide were used to localize the cytosolic free calcium and the Golgi apparatus by imaging their fluorescence individually. The results showed that the fluorescence of C6-NBD-ceramide and the highest fluorescence of fluo-3 were distributed identically in each phase of the cell cycle. The Golgi apparatus is especially retentive of $\mathrm{Ca}^{2+}$ when the plasma membrane was permeated by $10 \mu \mathrm{M}$ digitonin. It seems, therefore, that high concentration of free calcium is localized mainly in the Golgi apparatus.

\section{MATERIALS AND METHODS}

\section{Cells cultures}

NIH3T3 cells were seeded onto the glass coverslips and incubated in DMEM supplemented with $20 \%$ fetal bovine serum at $37{ }^{\circ} \mathrm{C}$ in $5 \% \mathrm{CO}_{2}$ atmosphere. Cells were used for experiments when they reached logarithmic phase.

\section{Vital staining of cytosolic free calcium and Golgi apparatus}

The cells grown on the coverslips were stained with $10 \mu \mathrm{M}$ fluo-3/ AM (molecular probe) for 30 min at $37{ }^{\circ} \mathrm{C}$, and washed with a standard medium (135 mM NaCl, $10 \mathrm{mM}$ HEPES, $0.4 \mathrm{mM} \mathrm{MgCl}$, $1 \mathrm{mM} \mathrm{CaCl} 2,0.1 \%$ D-glucose, $0.1 \%$ bovine serum albumin, $\mathrm{pH} 7.3$ ) at least 3 times. Then the cells were mounted on a small chamber containing the standard medium to maintain them in living state. For vital staining of Golgi apparatus, the cells were loaded with $\mathrm{C}_{6}$-NBD-ceramid (molecular probe) as previously described[9].

\section{Microscopy and image analysis systems[10]}

Comparable microscopic observations were done by using LSCFM (Carl Zeiss, Oberkochen, Germany) equipped with laser $488 \mathrm{~nm}$ excitation. An oil objective $\times 40 / 1.30$ was used. Observations were done at an image resolution of $512 \times 512$ pixels ( 8 bit). For digital processing the images were transferred to a DEC micro VAX II computer through an IEEE connector. TIPS (Delft University of Technology, the Netherlands) was used for digital processing. The images were taken by a timing 
videoprint. The stereo pairs of 3-D reconstructional images were obtained by processing a set of optical sections with the improved stereovisualization method described by Schormann et al[10].

Opening the plasma membrane with digitonin[11]

Exposing the cells loaded with fluo-3/AM in $\mathrm{Ca}^{2+}$-free standard medium containing $10 \mu \mathrm{M}$ digitonin, the cytosol calcium flowed out through the millipores on the plasma membrane.

\section{RESULTS}

The 3-D reconstructional image revealeda high intracellular calcium region in a perinuclear area

In non-confocal image (Fig 1a), the fluorescence of fluo-3 distributed homogeneously throughout the NIH3T3 cell and did not show any high $\mathrm{Ca}^{2+}$ region. Using LSCFM serial optical sections were obtained (Fig 1b-1f), and some of them showed that there was a high $\mathrm{Ca}^{2+}$ region in the perinuclear area. Reconstruction of these optical sections also showed clearly that the highest $\mathrm{Ca}^{2+}$ concentration was in the perinuclear region (Fig 2).

The regions of high perinuclear $\left[\mathrm{Ca}^{2+}\right] \mathrm{i}$ are associated with the Golgi apparatus in interphase cell

When different NIH3T3 cells were separately stained with fluo-3/AM and $\mathrm{C}_{6^{-}}$ NBD-ceramide, one could see that the highest $\mathrm{Ca}^{2+}$ concentration was detected in an area adjacent to the nucleus (Fig $3 \mathrm{a}$ ) and the $\mathrm{C}_{6}$-NBD-ceramide fluorescence was also found to be located asymmetrically around the nucleus (Fig $3 \mathrm{~b}$ ). When the same cell was first stained with fluo-3/AM and imaged by LSCFM, the cell was then exposed to liposomes containing $\mathrm{C}_{6}$-NBD-ceramide for $10 \mathrm{~min}$ and then postincubated at room temperature for $45 \mathrm{~min}$ to traffic the lipid probe to the Golgi apparatus before capturing another image. Such colocalization stainning was made possible since the fluorescence of $\mathrm{C}_{6}$-NBD-cermamide was far brighter than that of fluo-3, so that the interference of fluo-3 fluorescence to the former was almost negligible. In the same NIH3T3 cell. the hightest concentrations of $\left[\mathrm{Ca}^{2+}\right] \mathrm{i}$ in perinuclear area (Fig 4b) closely coincided with the location of the Golgi apparatus (Fig 4a). This study provided direct evidences that the Golgi apparatus might concentrate a high amount of free calcium.

The changes of distribution of intracellular free calcium and the Golgi apparatus in different phases of cell cycle

The distribution of cytosolic $\mathrm{Ca}^{2+}$ and Golgi apparatus in different phases of cell cycle was shown in Fig 5 and Fig 6. In metaphase (Fig 5a and 5b),the fluorescence of fluo-3 was uniformly distributed throughout the cell and there was no special high $\mathrm{Ca}^{2+}$ region. Since the Golgi complex disassembled during mitosis, the fluorescence of $\mathrm{C}_{6}$-NBD-ceramide was also diffusely dispersed throughout the cell. However, in telophase (Fig 6a and 6b), cytosolic free calcium became concentrated at the region 
Golgi apparatus concentrates high $\left[\mathrm{Ca}^{2+}\right] \mathrm{i}$

of spindle remnants, and so did the fluorescence of $\mathrm{C}_{6}$-NBD-ceramide.
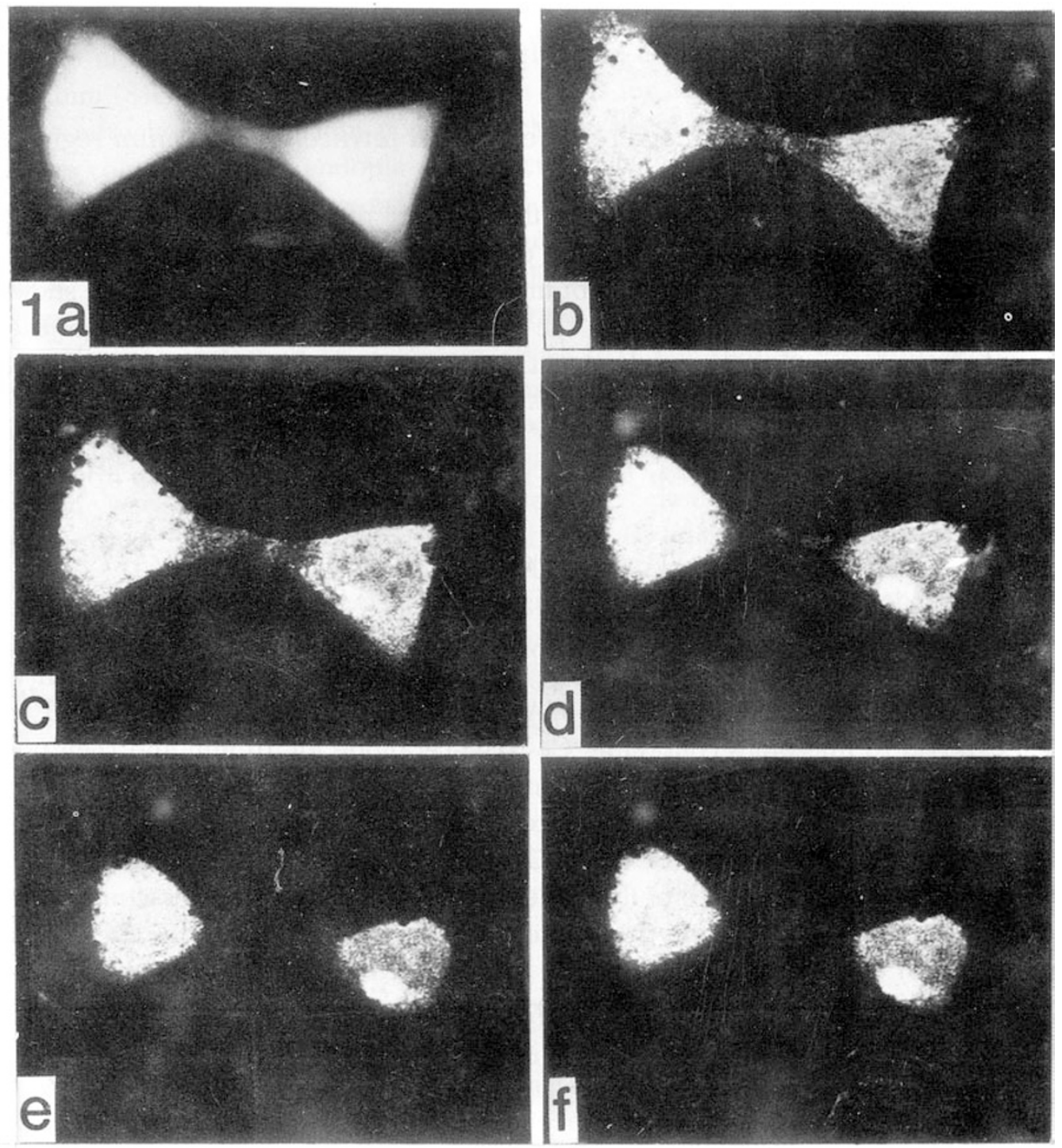

Fig 1. Fluo-3 fluorescence images of NIH3T3 cells. (a) The image was obtained without confocal micrscopy. (b-f) The LSCFM images of a serial optical sections from the matrix surface upwards. Some of the sections indicate a high-calcium perinuclear region. 
Fig 2. A stereo pair of photographs (should be observed under reflective steroscope), showing distribution of intracellular free calcium. NIH3T3 cells stained with fluo-3/AM.

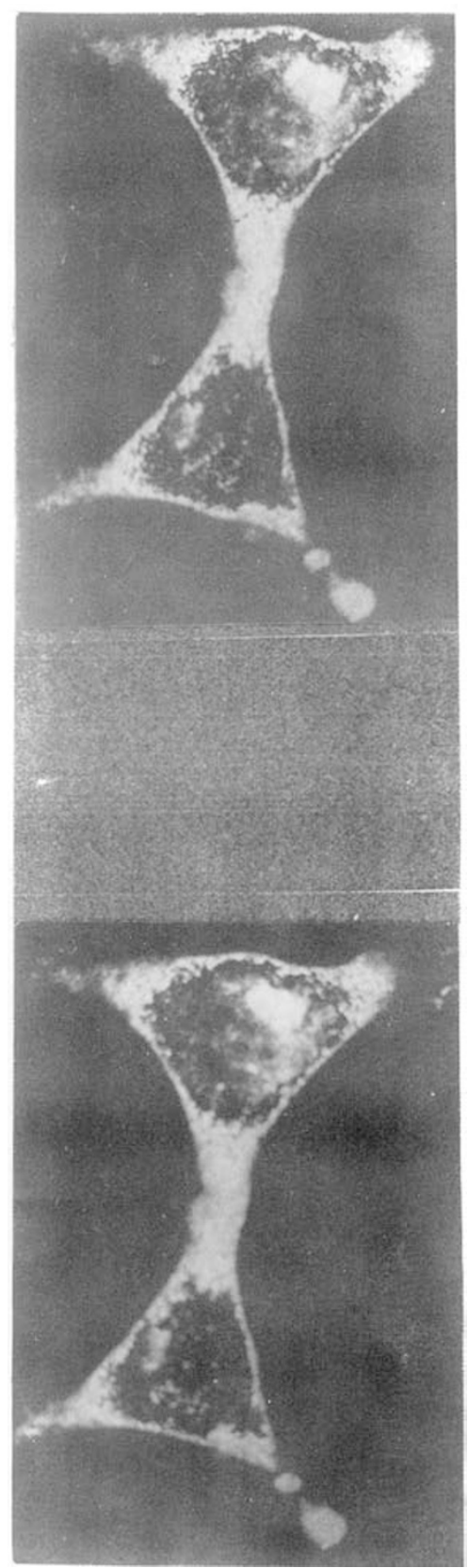

High retention of cytosolic free calcium in Golgi lumen

The decrease of cytosol calcium was investigated by permeating the cells with $10 \mu \mathrm{M}$ digitonin. The NIH3T3 cells were first loaded with $10 \mu \mathrm{M}$ fluo-3/ AM, then exposed to a calcium-free medium containing $10 \mu \mathrm{M}$ digitonin. Tab 1 showed the 
Golgi apparatus concentrates high $\left[\mathrm{Ca}^{2+}\right] \mathrm{i}$

changes of fluorescence in the Golgi and non-Golgi regions. It can be seen that the fluorescence in non-Golgi regions decreased $40 \%$ more than that in the Golgi area, suggesting a high retention of free calcium concentrated in the lumen of the Golgi apparatus.
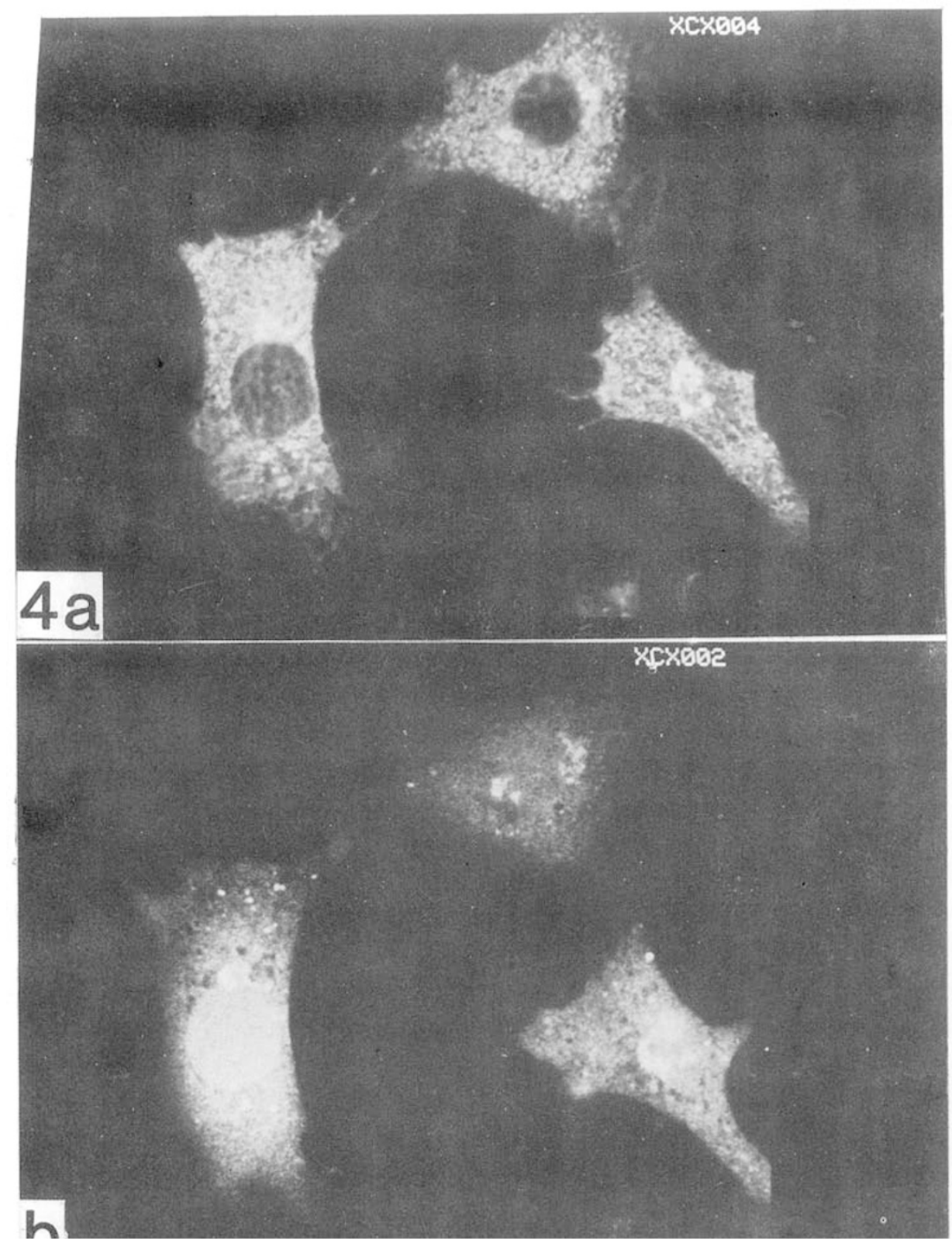

Fig 3. The LSFCM images of (a) fluo-3 fluorescence and (b) $\mathrm{C}_{6}$-NBD-ceramide fluorescence of 2 different NIH3T3 cells. 
Xue SB et al.
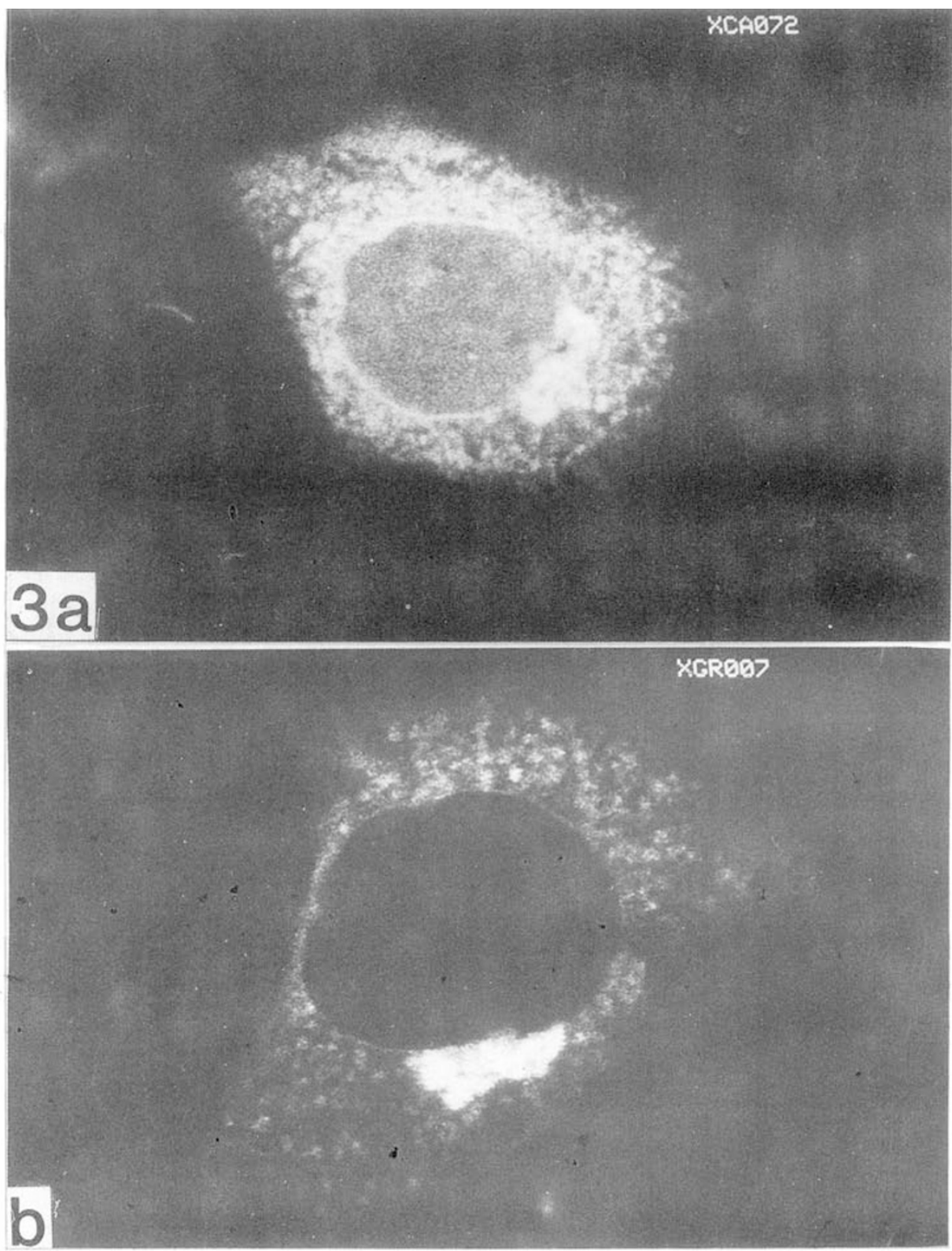

Fig 4. Co-localization of intracellular free calcium and Golgi apparatus in the same interphase NIH3T3 cell. (a) The fluorescence of $\mathrm{C}_{6}$-NBDceramide for Golgi apparatus. (b) The fluorescence of fluo-3 for $\mathrm{Ca}^{2+}$. The cell was first loaded with fluo-3/AM and imaged by LSCFM and then stained with $\mathrm{C}_{6}$-NBD-ceramide. The image of $\mathrm{C}_{6}$-NBD-ceramide was taken under the condition that the magnification of the signal was reduced to an absence of detectable fluo-3 fluorescence by decreasing the sensitivity of image detector. 
Golgi apparatus concentrates high $\left[\mathrm{Ca}^{2+}\right] \mathrm{i}$

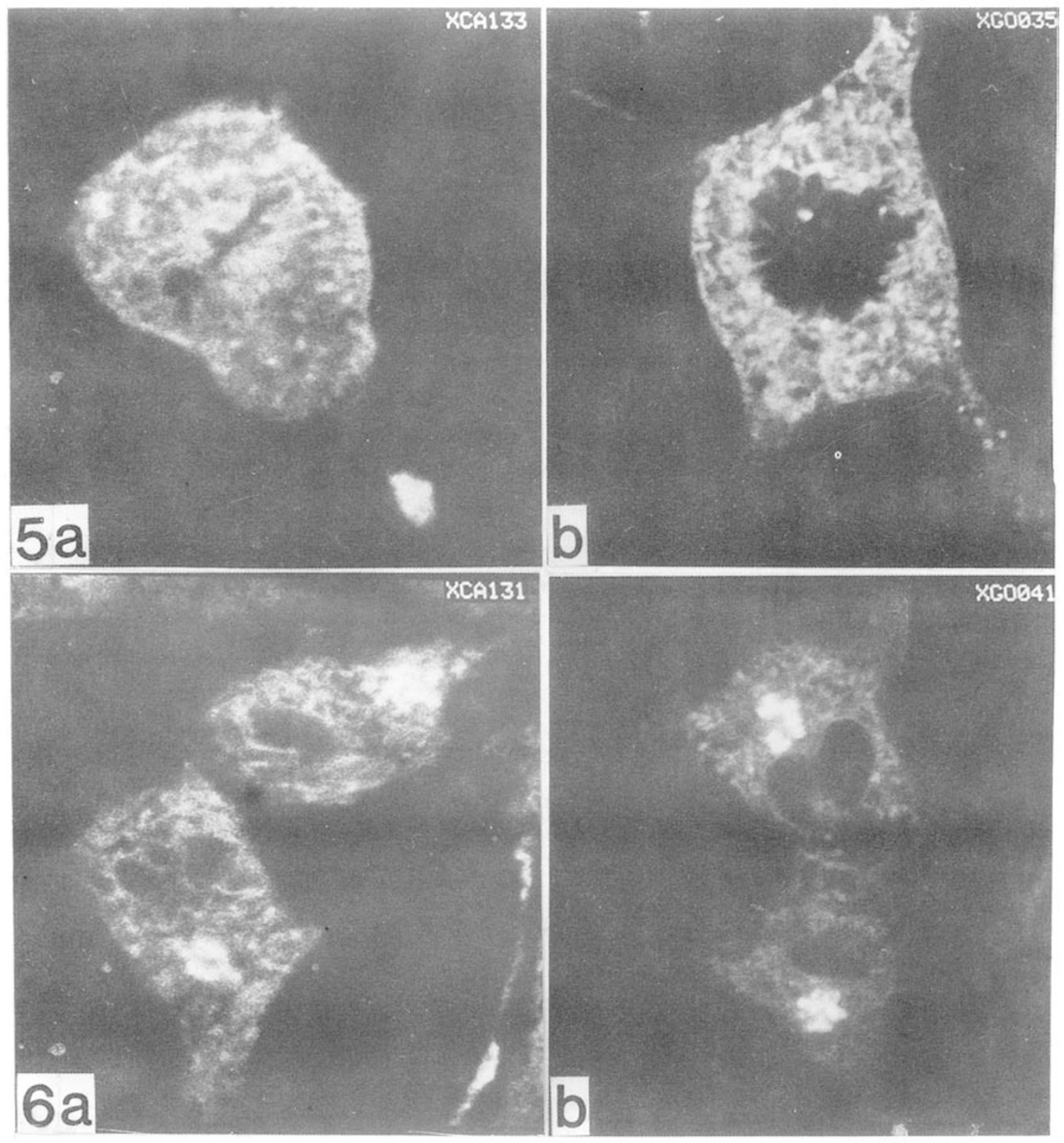

Fig 5. and Fig 6. The LSCFM images of fluo-3 fluorescence for intracellular free calcium (Fig 5a and Fig 6a) and corresponding $\mathrm{C}_{6}$ - NBD-ceramide fluorescence revealing Golgi apparatus (Fig $5 \mathrm{~b}$ and Fig $6 \mathrm{~b}$ ) of metaphase (Fig 5) and telophase (Fig 6) cells. 
Tab 1. The fluo-3 fluorescence of the cells with or without $10 \mu \mathrm{M}$ digitonin treatment

\begin{tabular}{ccc}
\hline & \multicolumn{2}{c}{ Fluo-3 Fluorescence } \\
\cline { 2 - 3 } & Golgi regions $^{(0)}$ & Non -Golgi region of cytosol \\
\hline Control cells & 143.46 & 64.68 \\
\hline 1min, $10 \mu$ M digitonin & 92.75 & 16.07 \\
\hline Fluorescence retention\% & $64.7 \%$ & $24.8 \%$ \\
\hline
\end{tabular}

(a) Relative intensity of fluo-3 fluorescence.

(b) Total relative fluorescent intensity in Golgi regions of more than 30 cells in 1 image.

(c) Total relative fluorescent intensity in non-Golgi cytosol of more than 30 cells in 1 image.

\section{DISCUSSION}

It has been noticed that there is a high $\mathrm{Ca}^{2+}$ region at the perinuclear area of a cell through the use of different calcium fluorescent indicator and other new techniques[12-15]. However, as the objective of conventional microscopy was limited by its axial resolution, the image of a point source produced by a diffraction-limited optical system is not only periodic around the point of focus in the focal plane, but also periodic above and below the focal plane along the axis of the microscope (outof-focus) [16]. It is difficult to determine whether the perinuclear high $\mathrm{Ca}^{2+}$ region is only a mask image since this area of the cell is thicker than that of any other regions. Since the Golgi apparatus is usually located at the perinuclear region and can be visualized with the fluorescent probe $\mathrm{C}_{6}$-NBD-ceramide, it is possible to colocalize the high $\mathrm{Ca}^{2+}$ region and the Golgi apparatus in a single cell. Recently Chandra et al demonstrated that Golgi apparatus sequestrated a high concentration of total calcium with LSCFM and ion microscopy[8]. Wahl et al have compared the spatial distribution of free $\mathrm{Ca}^{2+}$ gradients with the subcellular distribution of cytoplasmic organelles using calcium probe fura- 2 and organelle-specific fluorescent dyes and found the Golgi apparatus to be closely coincident with the highest concentration of $\left[\mathrm{Ca}^{2+}\right] \mathrm{i}[21]$. The present work confirmed these observations with LSCFM. The precise optical sections and the 3-D reconstruction images showed clearly the spatial distribution of the highest concentration of $\left[\mathrm{Ca}^{2+}\right] \mathrm{i}$ at perinuclear region in the living cell. Futher experiment for co-localization of the subcellular distribution of free calcium and Golgi apparatus with fluo-3/AM and $\mathrm{C}_{6}$-NBD-ceramide showed that the highest concentration of $\left[\mathrm{Ca}^{2+}\right] \mathrm{i}$ was associated with the Golgi apparatus in the same interphase NIH3T3 cell.In every cell cycle phase the distributions of highest concentration of $\left[\mathrm{Ca}^{2+}\right] \mathrm{i}$ and the Golgi apparatus were identical (Fig $4-6$ ). The results of digitonin experiment also revealed a prominent $\mathrm{Ca}^{2+}$ concentration in the Golgi lumen. Thus, it is the Golgi apparatus that concentrates a high amount of calcium ions. 
Golgi apparatus concentrates high $\left[\mathrm{Ca}^{2+}\right] \mathrm{i}$

In the present study, we also reported a technique for co-localizing the intracellular free calcium and the Golgi apparatus using the calcium probe fluo-3/AM and a fluorescent lipid $\mathrm{C}_{6}$-NBD-ceramide stains the Golgi apparatus prominently. $\mathrm{C}_{6}$ NBD-ceramide can also label mitochondria and ER, but the fluorescence emanating from these structures was indistinguishable from the background after 45 min poststaining incubation[9]. Although both fluo-3 and $\mathrm{C}_{6}$-NBD-ceramide can be excited at $488 \mathrm{~nm}$ and their fluorescence emission can not be separated by available barrier filter, the fluorescence of $\mathrm{C}_{6}$-NBD-ceramide was much brighter than that of fluo-3. When the image of the cells preloaded with fluo-3/AM was taken, the magnification of the fluorescence signal was reduced by decreasing the sensitivity of the image detector so that the fluorescence of fluo-3 can not be detected. And then the cell was stained with $\mathrm{C}_{6}$-NBD-ceramide. Under such a condition, there is no contribution of the fluo-3 fluorescence to the $\mathrm{C}_{6}$-NBD-ceramide fluorescent images. Therefore, it is possible to co-localize both the $\left[\mathrm{Ca}^{2+}\right] \mathrm{i}$ and the Golgi apparatus.

As for the subcellular storage of calcium in non-muscle system, besides mitochodria, it commonly attributed to the ER or calciosome. Besides containing high concentrations of $\mathrm{Ca}^{2+}$, the $\left[\mathrm{Ca}^{2+}\right]$ i stores should contain at least 3 kinds of proteins: $\mathrm{Ca}^{2+}$-ATPase, the low-affinity high-capacity calcium binding protein (such as calreticulin), and the calcium release channel (IP3 receptor et al). Although a number of experiments revealed that the ER or calciosome contained the IP3 receptor and the low-affinity high-capacity calcium binding protein[22], neither of them showing accurate localization with calcium. Several lines of indirect evidences also implicated the calcium store in the Golgi apparatus. It was demonstated that the Golgi apparatus presented a $\mathrm{Ca}^{2+}$ pump in human neutrophils[17] and lactating mammary epithelial cells[18 - 20]. Since the membrane traffic between ER and Golgi apparatus is a bidirectional one: in both forward and backword pathways [23], it is possible that the ER membrane protein, including calreticulin and IP3 receptor, can also be transferred from the ER to the Golgi membrane through transport vesicles. It is known that calcium plays an essential role in the function of Golgi apparatus, such as aggregation of proteins in sectetory vesicles[24] and exocytosis of calcium through secretory vesicles. Although whether Golgi apparatus is an adjustable $\left[\mathrm{Ca}^{2+}\right] \mathrm{i}$ pool remains to be clarified, it is out of question that high calcium ions are concentrated in the Golgi apparatus.

\section{ACKNOWLEDGEMENTS}

We thank Miss A von Bogen for her excellent assistance. We also thank Dr. Tom Jovin for helpful suggestions. 
Xue SB et al.

\section{REFERENCES}

[1] Carafoli E. Intracellular calcium homeostasis. Annu Rev Biochem 1987; 56:395-433.

[2] Jaclb R, Merritt JE, Hallam Tj, Rink Tj, Repetitive spikes in cytoplasmic calcium evoked by histamine in human endothelial cells. Nature 1988; 335:40-5.

[3] Tsien RW, Tsien RY. Calcium channels, stores, and oscillations. Annu Rev Cell Biol 1990; 6:715-60.

[4] Maclennan DH, Holland PC. Calcium transport m sarcoplasmic reticulum. Annu Rev Biophys Bioeng 1975; 4:377-404.

[5] Koch GLE. The endoplasmic reticulum and calcium storage. Bioessays 1990; 12:527-31.

[6] Volpe P, Krause K-H, Hashimoto S, et al. "Calciosome," a cytoplasmic organelle: The inositol 1, 4, 5-trisphosphate-sensitive Ca2+ store of nonmuscle cells? Proc Natl Acad Sci USA 1988; 85:1091-5.

[7] Hashimoto S, Bruno B, Lew DP, Pozzan T, Volpe P, Meldolesi J. Immunocytochemistry of calciosomes in liver and pancreas. J Cell Biol 1988; 107:2523-31.

[8] Chandra S, Kable EPW, Morrison GH, Webb WW. Calcium sequestration in the Golgi apparatus of cultured mammalian cells revealed by laser scanning confocal microscopy and ion microscopy. J Cell Sci 1991; 100:747-52.

[9] Lipsdy NG, Pagano RE. A vital stain for the Golgi apparatus. Science 1985; 228:745-7.

[10] Robet-Nicoud M, Arndt-Jovin DJ, Schormann T, Jovin TM. 3-D imaging of cell \& tissues using confocal laser sacnning microscopy \& digital processing. Euro J Cell Biol 1989; 48:49-54.

[11] Lemasters JJ, Nieminen A-L, Gores GJ, et al. Multiparameter digitized video microscopy (MDVM) of hypoxic cell injury. In Herman B, Jacobson K. eds. Optical microscopy for biology. Wiley-Liss, Inc. 1990:523-41.

[12] Steinberg SF, Bilezikian JP, Al-Awqati Q. Fura-2 fluorescence is localized to mitochondria in endothelial cells. Am J Physiol 1987; 253:c744-7.

[13]Rantan RR, Shelanski ML, Maxfield FR. Transition from metaphase to anaphase is accompanied by local changes in cytoplasmic free calcium in Pt K2 kidney epithelial cells. Proc Natl Acad Sci USA 1986; 83:5136-40.

[14] Hernandez-Cruz A, Sala F, Adams PR. Subcellular dynamics of [Ca2+]i, monitored with laser scanned confocal microscopy in a single voltage-clamped vertebrate neuron. Biophy J 1989; 55:216a.

[15] Chandra S, Gross D, Ling Y-C, Morrison GH. Quantitative imaging of free and total intracellular calcium in cultured cells. Proc Natl Acad Sci USA 1989; 86:1870-4.

[16] Inore S. Foundations of confocal scanned imaging in light microscopy. In: Pawley J. eds. The handbook of biological confocal microscopy. IMR Press. 1989:1-14.

[17] Krause K-H, Lew PD. Subcellular distribution of Ca2+ pumping sites in human neutrophils. J Clin Invest 1987; 80:107-16.

[18] Virk SS, Krik CJ, Shears SB. Ca2+ transport and Ca2+ dependent ATP hydrolysis by Golgi vesicles from lactating rat mammary glands. Biochem J 1985; 266:741-8.

[19] Yoshimoto A, Nakanishi K, Aazai T, Komine S. Effects of inositol 1,4,5,-trisphosphate on calcium relaease from the endoplasmic reticulum and Golgi apparatus in mouse mammary epithelial cells: A comparison during pregnancy and lactation. Cell Biochem Func 1990; 8:191-8.

[20] Bingham EW, Mcgranaghan MB, Wickham WD, Leung CT, Farrell HM, Jr. $\mathrm{Ca}^{2+}$-and $\mathrm{Mg}^{2+}$ ATPase in the Golgi apparatus and microsomes of the lactating mammary glands of cows. Ann NY Acad Sci 1992; 671:418-20.

[21] Wahl M, Sleight RG, Gruenstein E. Association of cyoplasmic free Ca2+ gradients with subcellular organelles. J cellular Physiol 1992; 150:593-609.

[22] Michalak M, Milner RE, Burns K, Opas M. Calreticulin. Biochem J 1992; 285:681-92.

[23] Lippincott-Schwartz J. Bidirectional membrane traffic between the endoplasmic reticulum and Golgi apparatus. Trends Cell Biol 1993; 3:81-8. 
Golgi apparatus concentrates high $\left[\mathrm{Ca}^{2+}\right] \mathrm{i}$

[24] Gerdes H-H, Rosa P, Phillips E, et al. The primary structure of human secretogranin II, a widespread tyrosinesulfated secretory granule protein that exhibits low $\mathrm{pH}$ - and calcium- induced aggregation. J Biol Chem 1989; 264:12009-15.

Received 21-9-1993 Revised 21-3-1994 Accepted 8-4-1994 